\title{
Effect of Increased Lung Expansion on Surfactant Protein mRNA Levels in Lambs
}

\author{
ANDREA L. LINES, MARCUS G. DAVEY, RICHARD HARDING, AND STUART B. HOOPER \\ Department of Physiology, Monash University, Victoria, 3800, Australia.
}

\begin{abstract}
ABS
Increased fetal lung expansion profoundly inhibits surfactant
protein gene expression and stimulates cellular proliferation in the
fetal lung. Our aim was to determine whether increased expansion
of the lung after birth, by the application of a continuous positive
airway pressure (CPAP) for $12 \mathrm{~h}$, inhibits surfactant protein gene
expression and stimulates cell division in lambs. Two week-old
lambs were randomly divided into 2 groups $(n=5$ for each),
sedated, and exposed to either no CPAP (controls) or $10 \mathrm{cmH} \mathrm{H}_{2} \mathrm{O}$ of
$\mathrm{CPAP}$ during a 12 -hour treatment period. After $2 \mathrm{~h}$ of the treatment,
${ }^{3} \mathrm{H}-$ thymidine was administered to each lamb (iv) to measure pul-
monary DNA synthesis rates over the following $10 \mathrm{~h}$ of treatment.
To assess the increase in lung expansion, functional residual capac-
ity (FRC) was measured before the start of the treatment period and
again at 6 and $12 \mathrm{~h}$. Compared with control lambs, a CPAP of 10
$\mathrm{cmH} \mathrm{H}_{2} \mathrm{O}$ increased FRC from $26.8 \pm 3.8 \mathrm{~mL} / \mathrm{kg}$ to $62.9 \pm 19.7$
$\mathrm{~mL} / \mathrm{kg}$ at $6 \mathrm{~h}$ and it remained elevated at $12 \mathrm{~h}(56.2 \pm 5.7 \mathrm{~mL} / \mathrm{kg})$.
Despite this large increase in end expiratory lung volume $(\mathrm{FRC})$, the
\end{abstract}
The fetal lung is maintained in an expanded state by the retention of liquid within the future airways, and this high degree of expansion plays a vital role in the growth and development of the lung $(1,2)$. The degree to which the fetal lungs are expanded by liquid not only determines the rate of lung tissue growth (3), but also profoundly influences the differentiated state of alveolar epithelial cells (4). As a result, there is a strong relationship between the degree of fetal lung expansion and the expression of the surfactant proteins, SP-A, SP-B, and SP-C (5-8). Increases in fetal lung expansion rapidly (within 2 days) reduce SP-A, SP-B, and SP-C mRNA levels (5), whereas continuous deflation of the fetal lung increases SP-C mRNA levels (5) and SP-A levels (7). Similarly, prolonged mechanical distension of alveolar epithelial cells in culture has been shown to reduce SP-B and SP-C mRNA levels (9). These data provide compelling evidence that, at least in the fetus, surfactant protein mRNA levels are regulated by the degree of lung expansion. However, it is not clear whether this relationship persists after birth, although

Received April 27, 2001; accepted June 8, 2001.

Correspondence and reprint requests: Dr. Stuart. B. Hooper, Department of Physiology, Monash University, Victoria, 3800, Australia; stuart hooper@med.monash.edu.au.

Supported by the National Health and Medical Research Council of Australia.
mRNA levels for SP-A, SP-B, and SP-C and DNA synthesis rates in lung tissue were not altered. The results of this study indicate that, in contrast to the fetus, an increase in end expiratory lung volume of $\sim 100 \%$ does not affect surfactant protein gene expression or pulmonary DNA synthesis rates in 2 week old lambs. Thus, the response of the lung to increases in lung expansion varies markedly before and after birth. (Pediatr Res 50: 720-725, 2001)

\section{Abbreviations}

CPAP, continuous positive airway pressure

FRC, functional residual capacity

SP, surfactant protein

PEEP, positive end expiratory pressure

$\mathbf{P a C O}_{2}$, partial pressures of carbon dioxide in arterial blood

$\mathbf{P a O}_{2}$, partial pressure of oxygen in arterial blood

$\mathrm{SaO}_{2}$, percentage oxygen saturation of $\mathrm{Hb}$ in arterial blood mechanical distension has been shown to affect SP expression in cultured epithelial cells from adult rats (9).

Although alterations in lung expansion are known to influence the release of pulmonary surfactant after birth (10-12), the effects on surfactant protein gene expression have not been well defined and the reported results are contradictory. For instance, increased lung expansion for $96 \mathrm{~h}$, using a positive end expiratory pressure (PEEP) of $2.5 \mathrm{cmH}_{2} \mathrm{O}$, did not affect SP-A content of surfactant in adult baboons (13). In contrast, ventilation of preterm lambs at a PEEP of $3 \mathrm{cmH}_{2} \mathrm{O}$ increased SP-A and SP-B mRNA levels after $10 \mathrm{~h}$ (14). Thus, it is unclear whether the inverse relationship between lung expansion and surfactant protein gene expression that exists prenatally (5) persists after birth. Hence, one of our aims was to determine the effect of increased lung expansion on surfactant protein mRNA levels in the air-filled lungs of normal lambs. We hypothesized that the inverse relationship between increased lung expansion and surfactant protein gene expression, recently described in fetal sheep (5), persists in normal lambs after birth.

Increased lung expansion in lambs was induced by administering a CPAP of $10 \mathrm{cmH}_{2} \mathrm{O}$. The CPAP was administered for $12 \mathrm{~h}$, as it has been previously shown that surfactant protein 
mRNA levels can be altered within $5-10 \mathrm{~h}$ in preterm lambs (14). We chose a CPAP of $10 \mathrm{cmH}_{2} \mathrm{O}$ in an attempt to increase the end expiratory lung volume to a level $(\sim 50 \mathrm{~mL} / \mathrm{kg})$ similar to that experienced by the fetal lung following $2 \mathrm{~d}$ of tracheal obstruction (3).

Studies using liquid ventilation and conventional forms of mechanical ventilation to expand the lung in postnatal animals have found that increased lung expansion promotes lung tissue growth $(15,16)$. Similarly, increased lung expansion is thought to drive the acceleration in lung growth following hemipneumonectomy (17). These data suggest that increased lung expansion also regulates lung growth after birth, just as it does in the fetus before birth $(1,2)$. However, studies in fetal sheep (3) indicate that the lung growth response to increased lung expansion is time-dependent and occurs over a much shorter time period $(2-3 \mathrm{~d})$ than that previously studied in newborn animals $(>2 \mathrm{wk})(15,16)$. Thus, our second aim was to determine the effect of short-term periods $(12 \mathrm{~h})$ of increased end expiratory lung volumes on pulmonary DNA synthesis rates in newborn lambs.

\section{METHODS}

Experimental animals. The lambs used in this study $(n=$ 10) were born spontaneously and then raised with their mothers (Merino $\times$ Border Leicester cross; $n=7$ ). At $7-10 \mathrm{~d}$ after birth, polyvinyl catheters were implanted into the femoral artery and vein of each lamb under general anesthesia (18). Anesthesia was induced and maintained by inhalation of halothane $\left(1 \%\right.$ to $5 \%$ in $\mathrm{O}_{2}$; Fluothane, Zeneca, ICI Operations Pty. Ltd., Australia). The catheters were tunnelled s.c. to the flank of the lamb where they were exteriorized. When the lambs had fully recovered from surgery, they were returned to their mothers.

Experimental protocol. On the day of study $(14.1 \pm 0.9 \mathrm{~d}$ after birth), lambs were randomly divided into 2 groups; a control group or a CPAP group. All lambs were sedated throughout the study, using pentobarbitone sodium (Nembutal, Rhone Merieux, Australia; diluted to $5 \mathrm{mg} / \mathrm{mL}$ with saline). Sedation was an ethical requirement as it was necessary to intubate the lambs to apply the CPAP. The control group of lambs $(n=5)$, were also intubated but breathed room air spontaneously at atmospheric pressure for $12 \mathrm{~h}$. The CPAP group $(n=5)$ also breathed spontaneously, but exhaled against a continuous positive pressure of $10 \mathrm{cmH}_{2} \mathrm{O}$. The respiratory circuit consisted of an inspiratory limb connected to a regulated supply of filtered air and an expiratory limb that contained a side port which regulated the end expiratory pressure within the circuit. This end expiratory pressure was maintained at 10 $\mathrm{cmH}_{2} \mathrm{O}$ by altering the level at which the outlet was placed under water. Airway pressure was recorded continuously (MacLab, Analogue Digital Instruments, Australia) via a salinefilled catheter attached to the endotracheal tube. After 2 hours, ${ }^{3} \mathrm{H}$ thymidine ( $1 \mathrm{mCi} / \mathrm{kg}$ body weight, i.v., ICN, Australia) was administered to measure pulmonary DNA synthesis rates over the final $10 \mathrm{~h}$ of the experiment.

The lambs' arterial oxygen saturations were measured using a pulse oximeter (Nellcor Inc., Phoenix, AZ. USA), and rectal temperatures were maintained at $39-40^{\circ} \mathrm{C}$, which is the normal temperature for these lambs (18). Blood glucose levels were measured at least hourly (Model 2300 STAT Glucose/ Lactate analyser, YSI Bioanalytical Products, USA) and were maintained by administration of glucose $(5 \%$; i.v.) as required.

Physiologic measurements. Arterial blood samples (0.6 $\mathrm{mL}$ ) were collected hourly, and analyzed for $\mathrm{pH}$, partial pressures of carbon dioxide $\left(\mathrm{PaCO}_{2}\right)$ and oxygen $\left(\mathrm{PaO}_{2}\right)$, and percentage oxygen saturation of $\mathrm{Hb}\left(\mathrm{SaO}_{2}\right)$, using a blood gas acid/base analyser (ABL510, Radiometer, Denmark), and were adjusted for rectal temperature.

The volume of air remaining in the lung at end-expiration (functional residual capacity; FRC) was measured at 0,6 , and $12 \mathrm{~h}$ using a closed-circuit helium dilution method as previously described $(19,20)$ for use in small animals. To avoid the loss of He during the FRC measurement, lambs exposed to CPAP were rapidly switched from the CPAP circuit to the closed spirometer circuit at end expiration using a solenoid valve. Although CPAP could not be maintained during the FRC measurement, the volume lost from the lungs after switching to the spirometer circuit, due to the loss of an end expiratory pressure, entered the spirometer and, therefore, remained within the circuit for measurement. The volume of FRC was corrected for body temperature and pressure, saturated with water vapor.

At the end of the experimental period, each lamb was killed by an i.v. overdose of sodium pentothal (Lethabarb, $325 \mathrm{mg}$ / $\mathrm{mL}$, Virbac, Australia). The weight of the lamb and its lung, heart, liver, and kidneys were recorded. The lung was cut into small portions, snap frozen in liquid nitrogen, and then stored at $-70^{\circ} \mathrm{C}$. All experimental procedures on animals were approved by the Monash University Animal Ethics and Experimentation Committee.

Biochemical analysis. Total RNA was extracted from lung tissue using a modified guanidine thiocyanate-cesium chloride method (21). Surfactant protein mRNA levels were determined by Northern blot analysis as described previously (5). We used the same ${ }^{32} \mathrm{P}$-labeled cDNA probes, and the density of bands were analyzed using a phosphor-imager (Molecular Dynamics). To standardize the amount of total RNA $(20 \mu \mathrm{g})$ loaded onto each lane within a gel, each blot was stripped and reprobed with a ${ }^{32} \mathrm{P}$-labeled cDNA probe for 18S rRNA (5). Each Northern blot was repeated at least twice to ensure that the results obtained were reproducible. Pulmonary DNA content and DNA synthesis rates were analyzed as previously described (22).

Statistical analysis. All data are presented as mean ( \pm SEM) and the level of significance is $p<0.05$, unless otherwise stated. Differences in mean body weights, organ weights, DNA synthesis rates, and DNA content between control lambs and lambs exposed to CPAP were analyzed by unpaired $t$ tests. Blood gas measurements were grouped into 2-hour blocks for each experimental group, and differences between groups were analyzed by a two-way ANOVA for repeated measures. Differences between individual data points were then identified using a Fisher's least significant difference multiple comparison procedure. Similarly, differences in FRC measurements for each group at 0,6 , and $12 \mathrm{~h}$ were analyzed by a two-way 
repeated measures ANOVA. In all Northern blots, comparisons in SP-A, SP-B, and SP-C mRNA levels were only made between control and CPAP treated lambs that were included in the same blot. This ensured that the samples were exposed to the same hybridization conditions and exposure times. The total integrated density of each SP-A, SP-B, and SP-C transcript was divided by the total integrated density of the $18 \mathrm{~S}$ rRNA band for each lane. This gave a corrected density for each band that accounted for minor RNA loading differences between lanes. Differences in the surfactant protein mRNA to $18 \mathrm{~S}$ rRNA ratios between the control lambs and lambs exposed to CPAP were compared by a Student's unpaired $t$ test.

\section{RESULTS}

Gestational ages at delivery, body weights, and organ weights. All lambs were born at normal term $(147.1 \pm 0.9 \mathrm{~d}$ gestation) and at the expected birth weight $(3.95 \pm 0.33 \mathrm{~kg})$ for this breed of sheep. One lamb was from a singleton pregnancy and nine were from twin pregnancies. Following completion of the experiments, the body weights $(\mathrm{kg})$ of the lambs and the weights of their lungs, hearts, kidneys and livers $(\mathrm{g} / \mathrm{kg}$ body weight) were similar in both groups (Table 1).

Blood gas parameters. Following the onset of sedation, mean arterial $\mathrm{pH}$ in both control and CPAP treated lambs tended to decrease compared with the presedation value, although the fall was not statistically significant (Fig. 1). Such a reduction has been reported previously and may be attributed to an effect of pentobarbital sedation on respiratory control (18). In lambs exposed to CPAP, arterial $\mathrm{pH}$ tended to be reduced and the $\mathrm{PaCO}_{2}$ tended to be elevated, compared with control lambs, although these differences were not significant at any time point (Fig. 1). This is indicative of a mild hypoventilation in CPAP lambs, although the finding that the $\mathrm{SaO}_{2}$ levels were similar indicates that these lambs were not hypoxic.

Functional residual capacity. FRC measured before the start of the experimental period was similar in control (31.4 \pm $1.3 \mathrm{~mL} / \mathrm{kg})$ and CPAP treated lambs $(38.7 \pm 6.6 \mathrm{~mL} / \mathrm{kg}$; Fig. 2). In control lambs, the FRC measured at $6(26.8 \pm 3.8$ $\mathrm{mL} / \mathrm{kg})$ and $12(28.2 \pm 3.7 \mathrm{~mL} / \mathrm{kg}) \mathrm{h}$ of the treatment period was not different to that measured at the start $(0 \mathrm{~h})$. In the CPAP group, the FRC was significantly increased to $62.9 \pm$ $19.7 \mathrm{~mL} / \mathrm{kg}$ compared with control lambs after $6 \mathrm{~h}$. At $12 \mathrm{~h}$ of $\mathrm{CPAP}$, the FRC was $56.2 \pm 5.7 \mathrm{~mL} / \mathrm{kg}$ which was also significantly higher than values measured at the same time in control lambs. Thus, compared with control animals, 10 $\mathrm{cmH}_{2} \mathrm{O}$ of CPAP increased FRC by approximately $100 \%$.

Table 1. Body weights and organ weights (mean \pm SEM) of control lambs and lambs exposed to $12 \mathrm{~h}$ of $\mathrm{CPAP}$ at $10 \mathrm{~cm} \mathrm{H}_{2} \mathrm{O}$ measured at postmortem examination

\begin{tabular}{lcc}
\hline & Control $(n=5)$ & CPAP $(n=5)$ \\
\hline Body weight $(\mathrm{kg})$ & $7.221 \pm 0.297$ & $6.515 \pm 0.970$ \\
Organ weights $(\mathrm{g} / \mathrm{kg})$ & & \\
Lung & $16.8 \pm 1.9$ & $18.1 \pm 0.8$ \\
Heart & $6.1 \pm 0.9$ & $7.6 \pm 0.3$ \\
Liver & $22.9 \pm 1.1$ & $25.3 \pm 0.3$ \\
Kidneys & $6.3 \pm 0.6$ & $7.8 \pm 0.6$ \\
\hline
\end{tabular}
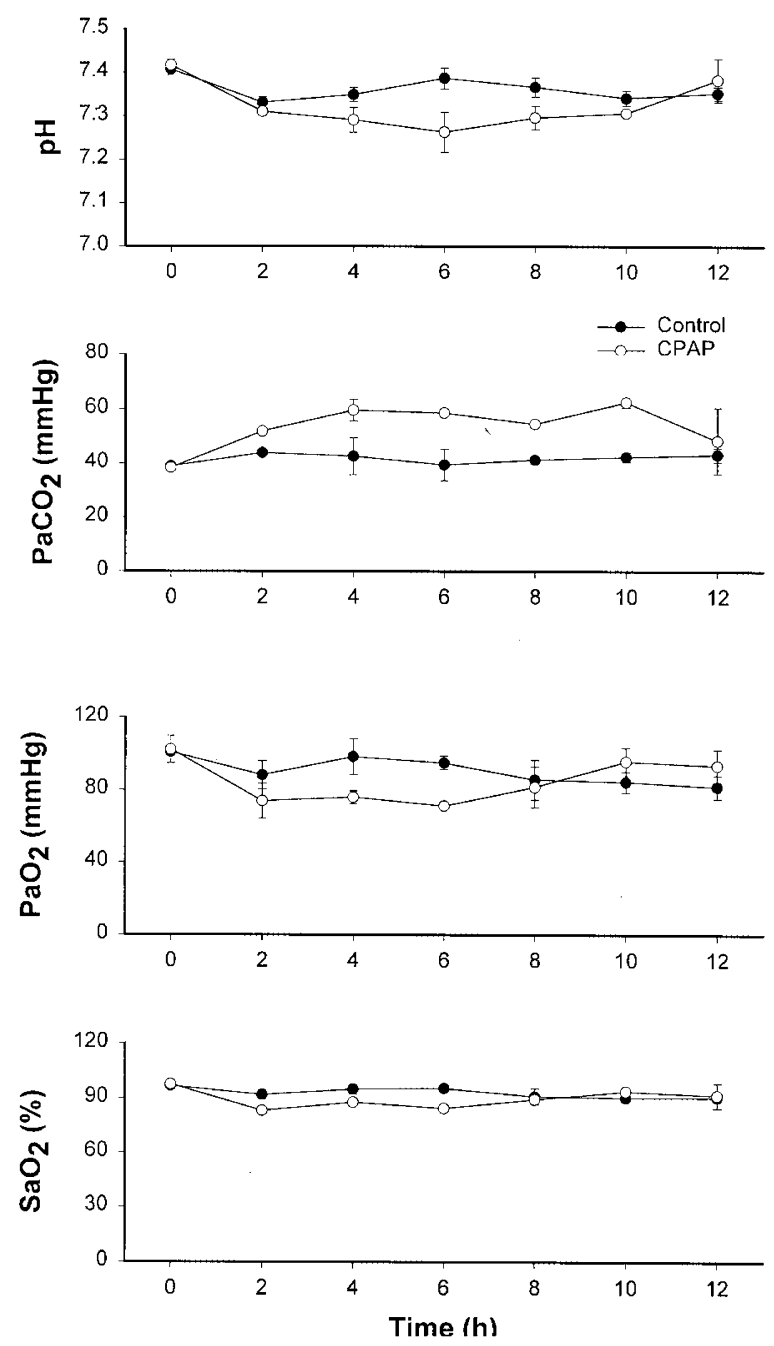

Figure 1. Changes (mean $\pm \mathrm{SEM}$ ) in arterial blood $\mathrm{pH}, \mathrm{PCO}_{2}\left(\mathrm{PaCO}_{2}\right), \mathrm{Po}_{2}$ $\left(\mathrm{PaO}_{2}\right)$ and percent oxygen saturation of $\mathrm{Hb}\left(\mathrm{SaO}_{2}\right)$ measured throughout the $12 \mathrm{~h}$ experimental period in control lambs (closed circles) and lambs exposed to $\mathrm{CPAP}$ at $10 \mathrm{cmH}_{2} \mathrm{O}$ (open circles).

Northern Blot Analysis. The application of $10 \mathrm{cmH}_{2} \mathrm{O}$ of CPAP for $12 \mathrm{~h}$ tended to increase fetal lung SP-C mRNA levels (CPAP, $36.0 \pm 3.1$ versus controls $26.1 \pm 3.7 ; p=0.07$ ) although the difference was not statistically significant (Fig. 3). The mRNA levels for SP-A (CPAP, $61.5 \pm 8.8$ versus controls, $49.1 \pm 11.0$ ) and SP-B were similar (CPAP, $11.9 \pm 1.3$ versus controls, $10.9 \pm 1.6$ ) in both groups of lambs (Fig. 3).

DNA content and DNA synthesis rates. A CPAP of 10 $\mathrm{cmH}_{2} \mathrm{O}$ did not alter the incorporation of ${ }^{3} \mathrm{H}$ - thymidine into DNA $(76.3 \pm 12.0 \mathrm{dpm} / \mu \mathrm{g}$ of DNA) from control levels ( 68.5 $\pm 15.5 \mathrm{dpm} / \mu \mathrm{g}$ of DNA). This indicates that pulmonary DNA synthesis rates were not altered by $12 \mathrm{~h}$ of increased FRC (Fig. 4). Similarly, total DNA content of the lungs in control lambs $(59.22 \pm 6.82 \mathrm{mg} / \mathrm{kg})$ was not different from that measured in lambs exposed to $10 \mathrm{cmH}_{2} \mathrm{O}$ of CPAP for $12 \mathrm{~h}(58.72 \pm 4.19$ $\mathrm{mg} / \mathrm{kg}$ ).

\section{DISCUSSION}

This study has demonstrated that $12 \mathrm{~h}$ of CPAP, maintained at $10 \mathrm{cmH}_{2} \mathrm{O}$, increased end expiratory lung volumes in lambs 


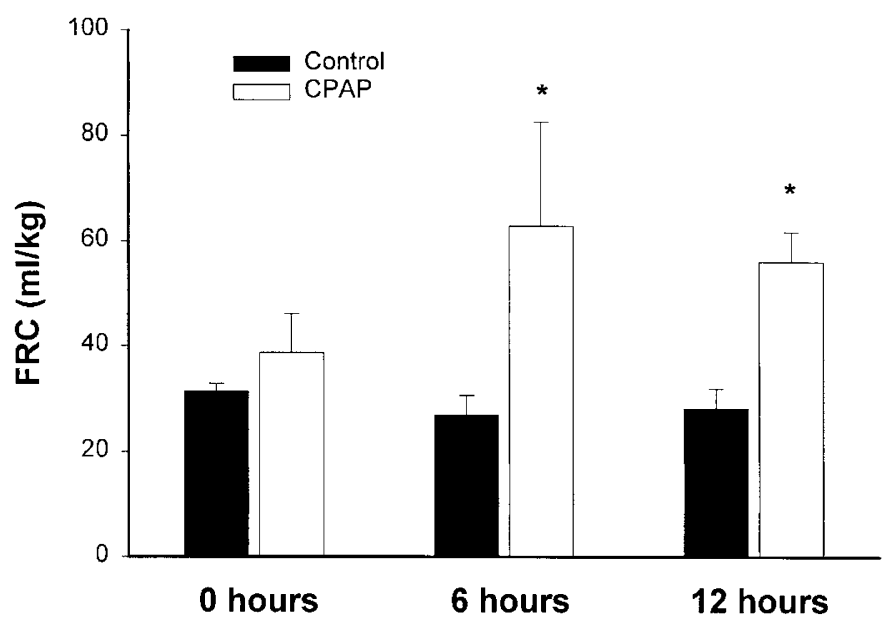

Figure 2. Functional residual capacity (FRC; mean $\pm \mathrm{SEM}$ ) measured in control lambs (solid bars) and lambs exposed to CPAP at $10 \mathrm{cmH}_{2} \mathrm{O}$ (open bars) at $0 \mathrm{~h}$ (before the application of CPAP) and at 6 and $12 \mathrm{~h}$ of the experimental period. Asterisks indicate values that are significantly different from control values measured at the same time point.

to $50-60 \mathrm{~mL} / \mathrm{kg}$, which is approximately double the FRC measured in control lambs. However, this increase in FRC was not associated with a reduction in SP-A, SP-B, or SP-C mRNA levels, or an increase in pulmonary DNA synthesis rates. In contrast, similar increases in lung expansion in ovine fetuses (i.e. to $50-60 \mathrm{~mL} / \mathrm{kg}$ ) greatly reduce surfactant protein mRNA levels and increase pulmonary DNA synthesis rates by $\sim 800 \%$ $(3,5,22)$. Thus, the results of this study indicate that the relationships between lung expansion and both lung growth and surfactant protein gene expression may be different between the liquid-filled fetal lung and the air-filled lung after birth. These results have important clinical significance as positive end expiratory pressures are commonly used when ventilating patients (particularly newborn infants) with mechanical ventilators.

There are several possible explanations for our inability to alter surfactant protein mRNA levels in response to increased lung expansion in lambs. It is possible that $12 \mathrm{~h}$ was insufficient time to induce changes in surfactant protein gene expression, although we believe this to be unlikely. Indeed, 5-10 h of ventilation, using a PEEP of $3 \mathrm{cmH}_{2} \mathrm{O}$, is sufficient time to alter SP-A and -B mRNA levels in the lung of preterm lambs (14). This fact suggests that transcriptional activity of the surfactant proteins can be rapidly altered in response to the appropriate stimuli. This suggestion is supported by other studies showing that surfactant protein mRNA levels can be altered within $24 \mathrm{~h}$ in premature baboons (23). However, it is not known whether transcriptional activity in fetal sheep and preterm lambs is similar to that of normal postnatal lambs, particularly as the endocrine environment is very different. Thus, it is questionable whether extrapolations between fetal/preterm animals and normal postnatal animals are valid. Nevertheless, we consider that $12 \mathrm{~h}$ of CPAP should have been sufficient time to induce a measurable change in surfactant protein mRNA levels, particularly as the increase in lung volume is likely to have been immediate. That is, the application of CPAP must cause an immediate increase in end expiratory lung volume (FRC) in the air-filled lung. In contrast, in fetal studies, the lung liquid volume can only increase at the rate liquid is being secreted (3-4 $\mathrm{mL} / \mathrm{kg}$ ) following tracheal obstruction, thereby taking at least $10-12 \mathrm{~h}$ for lung volume to reach $50-60 \mathrm{~mL} / \mathrm{kg}$ (3).

In this study, the lambs were exposed to a CPAP of 10 $\mathrm{cmH}_{2} \mathrm{O}$, which is slightly higher than that previously used in ferret pups $\left(6 \mathrm{cmH}_{2} \mathrm{O}\right)$ to study the effect on postnatal lung growth (15). It is also higher than that used in premature lambs $\left(3-4 \mathrm{cmH}_{2} \mathrm{O}\right)$ to study the effect of PEEP on SP expression and surfactant metabolism $(14,24)$. We did not use higher CPAP levels as these can cause lung damage (25) which can lead to inactivation of surfactant. Nevertheless, we successfully increased the end expiratory lung volumes in lambs, relative to body weight, to a level similar to that observed in fetal sheep at $2 \mathrm{~d}$ of tracheal obstruction $(\sim 55 \mathrm{~mL} / \mathrm{kg})(3)$. However, this represented a $99.3 \%$ increase in end expiratory lung volume above control lambs (at 12 hours), which is higher than the percentage increase (above controls) observed in fetal sheep following $2 \mathrm{~d}$ of tracheal obstruction (75.5\%). Despite the slightly larger percentage increase in lung expansion, surfactant protein mRNA levels were not altered in lambs exposed to CPAP, which contrasts with the large decrease observed in fetal sheep at $2 \mathrm{~d}$ of tracheal obstruction (5). It is possible that this level of expansion in an air-filled lung was not sufficient to induce trans-differentiation of type II alveolar epithelial cell (AEC) phenotype. Trans-differentiation is the most likely explanation for the reduction in surfactant protein mRNA levels that occurs in the fetal lung after an increase in lung expansion (4). For instance, the presence of surface tension within the air-filled alveoli may alter the way forces are transmitted onto individual epithelial cells, possibly by limiting the degree of alveolar wall stretch. It is difficult to estimate how much stretch was applied to the alveolar epithelium as a result of applying a $10 \mathrm{cmH}_{2} \mathrm{O}$ CPAP to the airways. However, a previous study has estimated that, in isolated and partially inflated lungs, a $10 \mathrm{cmH}_{2} \mathrm{O}$ increase in airway pressure can increase alveolar surface area by $\sim 30 \%$.

Apart from the differences in the medium and the potential contribution of surface tension, the different responses in surfactant protein expression between lambs and fetuses may also relate to differences in the characteristics of the lung expansion. In fetal studies, following the initial increase in lung expansion associated with tracheal obstruction, the expansion is essentially iso-volumetric (3), as no volume change can occur during breathing movements. On the other hand, the application of CPAP in air-breathing lambs causes a sustained increase in end-expiratory lung volume (from $28.2 \pm 3.7$ to $56.2 \pm 5.7$ $\mathrm{mL} / \mathrm{kg}$ at $12 \mathrm{~h}$ ), but superimposed on this is phasic expansion of the lung due to breathing activity. Tidal volumes are $\sim 7 \mathrm{~mL} / \mathrm{kg}$ in lambs at this age (19) and, therefore, even after the application of CPAP, the phasic change in lung volume associated with breathing activity is at least $10 \%$. Phasic stretch has been shown to influence DNA synthesis rates in type II AECs from adult lungs (26) and to stimulate surfactant protein $\mathrm{C}$ mRNA levels in vitro (27). Phasic stretch may, therefore, modify the effect of constant stretch on the type II AEC phenotype in vivo.

Other explanations for the differences in surfactant protein expression between fetuses and lambs in response to increases 

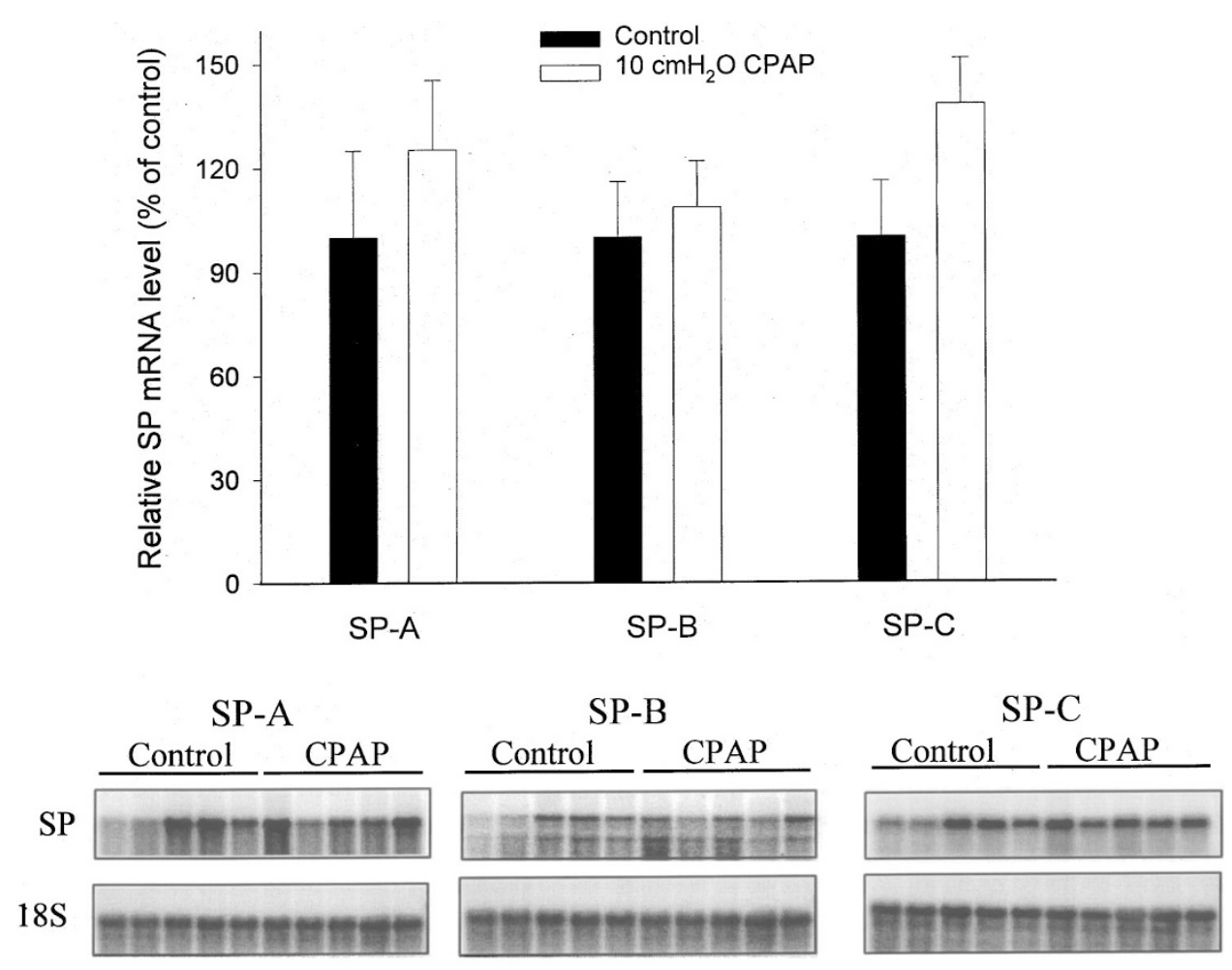

Figure 3. Upper panel: Surfactant protein-A (SP-A), surfactant protein-B (SP-B) and surfactant protein-C (SP-C) mRNA levels in lung tissue collected from control lambs (solid bars) and lambs subjected to CPAP for $12 \mathrm{~h}$ at $10 \mathrm{cmH}_{2} 0$ (open bars). The levels of SP mRNA are corrected for 18S rRNA levels and are expressed as a percentage of the mean control value from control samples that were run on the same blot. Lower panel: Representative Northern blots for SP-A, $-\mathrm{B}$ and $-\mathrm{C}$ in control spontaneously breathing lambs and lambs exposed to $12 \mathrm{~h}$ of CPAP; each lane represents a different lamb. The $18 \mathrm{~S}$ ribosomal RNA bands were used to adjust for minor total RNA loading differences between lanes

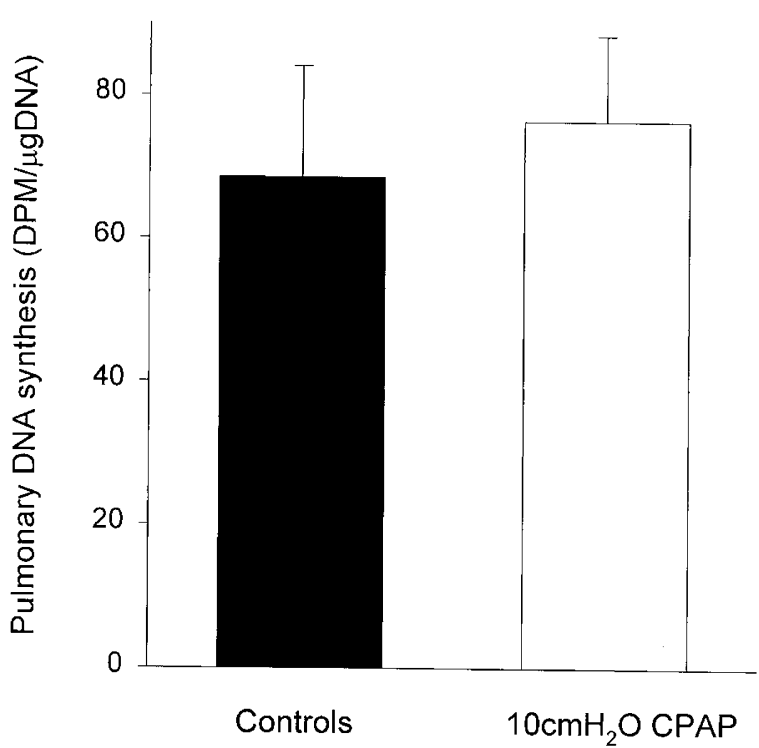

Figure 4. Pulmonary DNA synthesis rates (mean \pm SEM) measured in control lambs (solid bars) and lambs subjected to CPAP for $12 \mathrm{~h}$ at $10 \mathrm{cmH}_{2} 0$ (open bars). DNA synthesis rates were determined by measuring the incorporation of ${ }^{3} \mathrm{H}$-thymidine into DNA over the last $10 \mathrm{~h}$ period of the experiment.

in lung expansion may relate to the degree of lung maturity or an effect of sedation. The transmission of a mechanical force via the lung parenchyma must be dependant on the structure and composition of the extracellular matrix (ECM). As the lung undergoes marked structural changes late in gestation
(28), the transmission of mechanical forces, resulting from alterations in lung expansion, onto individual alveolar epithelial cells may markedly change as the lung matures. Alternatively, it is possible that the different responses in lambs and fetuses may relate to type-II cell maturation, although we consider this to be unlikely. The previous study, which has shown an effect of CPAP on surfactant protein mRNA levels, was performed on premature lambs (14) whereas surfactant protein mRNA levels are not altered by $96 \mathrm{~h}$ of increased lung expansion in adult baboons (13). However, other evidence exists to suggest that the relationship between alveolar epithelial cell shape, phenotype, and mechanical forces persists in the adult lung. Indeed, in vitro studies that have examined these relationships have predominantly been performed using alveolar epithelial cells from adult lungs (29). Furthermore, the finding that the proportion of type II AECs is increased within a fibrotic lesion (30), associated with lung fibrosis, is consistent with the concept that a relationship between lung mechanics and AEC phenotype persists in the adult. It is also unlikely that sedation obscured an effect of CPAP on surfactant protein mRNA levels, as the previous study, which reported an alteration in SP mRNA levels with CPAP, also used sedated lambs (14).

It is important to note that the increase in FRC in lambs was measured following connection to a spirometer and was, therefore, made at atmospheric pressure. It is possible, therefore, that our FRC measurement may overestimate the true end expiratory lung volume in CPAP lambs because of gas com- 
pression within the lungs. However, calculation of the change in volume associated with a reduction in pressure of $10 \mathrm{cmH}_{2} \mathrm{O}$ demonstrates that this could only account for a change of $\sim 1 \%$ of lung volume in these lambs. It should be noted that, although the removal of CPAP during the FRC measurement would briefly cause a loss of gas volume from the lamb, this volume entered the spirometer and, therefore, remained within the respiratory circuit. Thus, the measurement of FRC is likely to be an acceptably accurate measure of the increase in lung volume. In addition, lambs exposed to CPAP tended to have elevated $\mathrm{PaCO}_{2}$ and a reduced $\mathrm{pH}$, which is indicative of a mild hypoventilation, although they were clearly not hypoxic. The effect that this may have on surfactant protein expression is unknown. However, it is unlikely that these small insignificant changes in blood gases could have prevented a large reduction in surfactant protein mRNA levels similar to that observed in fetal sheep following tracheal obstruction (5).

The increase in lung volume induced by the application of CPAP for $12 \mathrm{~h}$ at $10 \mathrm{cmH}_{2} \mathrm{O}$ did not induce changes in cell division rates, as measured by ${ }^{3} \mathrm{H}$-thymidine incorporation into DNA, or total lung DNA contents. In contrast, previous studies have shown that the application of CPAP $\left(6 \mathrm{cmH}_{2} \mathrm{O}\right)$ for 2 weeks stimulated lung growth in ferret pups (15). Similarly, increased lung expansion for $21 \mathrm{~d}$ (but not $7 \mathrm{~d}$ ) in lambs, using a liquid perfluorocarbon, has been shown to stimulate lung growth $(16,31)$. Combined with the findings of our study, these results suggest that, in comparison with the fetus, the acceleration in lung growth induced by an increase in lung expansion is delayed in postnatal animals. The reason for this is unknown, but it may relate to differences in GH concentrations. Circulating GH concentrations are high in fetal sheep and decrease markedly after birth (32). As the acceleration in fetal lung growth induced by an increase in lung expansion is GH dependent (33), it is possible that the lung growth response to increased lung expansion after birth is delayed because of lower GH concentrations at this time.

In conclusion, the application of CPAP at $10 \mathrm{cmH}_{2} \mathrm{O}$ for $12 \mathrm{~h}$ increased end expiratory lung volumes in 14-d old lambs by $\sim 100 \%$. However, this increase in lung expansion was not associated with changes in surfactant protein mRNA levels or lung growth after $12 \mathrm{~h}$. It is possible that a greater level of lung expansion is required to induce changes in surfactant protein gene expression and that more than $12 \mathrm{~h}$ of increased lung expansion is required to induce a measurable increase in lung growth after birth.

Acknowledgment. The authors gratefully acknowledge the expert technical assistance provided by Ms. Alison Thiel.

\section{REFERENCES}

1. Hooper SB, Harding R 1995 Fetal lung liquid: a major determinant of the growth and functional development of the fetal lung. Clin Exp Pharmacol Physiol 22:235-247

2. Harding R, Hooper SB 1996 Regulation of lung expansion and lung growth before birth. J Appl Physiol 81:209-224

3. Nardo L, Hooper SB, Harding R 1998 Stimulation of lung growth by tracheal obstruction in fetal sheep: relation to luminal pressure and lung liquid volume. Pediatr Res 43:184-190
4. Flecknoe S, Harding R, Maritz G, Hooper SB 2000 Increased lung expansion alters the proportions of type I and type II alveolar epithelial cells in fetal sheep. Am J Physiol Lung Cell Mol Physiol 278:L1180-L1185

5. Lines A, Nardo L, Phillips ID, Possmayer F, Hooper SB 1999 Alterations in lung expansion affect surfactant protein $\mathrm{A}, \mathrm{B}$ and $\mathrm{C}$ mRNA levels in fetal sheep. Am J Physiol 276:L239-L245

6. Piedboeuf B, Laberge J-M, Ghitulescu G, Gamache M, Petrov P, Belanger S, Chen M-F, Hashim E, Possmayer F 1997 Deleterious effect of tracheal obstruction on type 2 pneumocytes in fetal sheep. Pediatr Res 41:473-479

7. Joe P, Wallen LD, Chapin CJ, Lee CH, Allen L, Han VKM, Dobbs LG, Hawgood S, Kitterman JA 1997 Effects of mechanical factors on growth and maturation of the lung in fetal sheep. Am J Physiol 16:L95-L105

8. De Paepe ME, Papadakis K, Johnson BD, Luks FI 1998 Fate of the type II pneumocyte following tracheal occlusion in utero: a time-course study in fetal sheep. Virchows Arch 432:7-16

9. Gutierrez JA, Gonzalez RF, Dobbs LG 1998 Mechanical distension modulates pulmonary alveolar epithelial phenotypic expression in vitro. Am J Physiol 274:L196-L202

10. Wyszogrodski I, Kyei-Aboagye K, Taeusch HW, Jr., Avery ME 1975 Surfactant inactivation by hyperventilation: conservation by end-expiratory pressure. J Appl Physiol 38:461-466

11. Nicholas TE, Barr HA 1983 The release of surfactant in rat lung by brief periods of hyperventilation. Respir Physiol 52:69-83

12. Hildebran JN, Goerke J, Clements JA 1981 Surfactant release in excised rat lung is stimulated by air inflation. J Appl Physiol 51:905-910

13. Simonson SG, Huang YC, Fracica PJ, Welty-Wolf KE, Moon RE, Young SL, Piantadosi CA 1997 Changes in the lung after prolonged positive pressure ventilation in normal baboons. J Crit Care 12:72-82

14. Woods E, Ohashi T, Polk D, Ikegami M, Ueda T, Jobe AH 1995 Surfactant treatment and ventilation effects on surfactant SP-A, SP-B, and SP-C mRNA levels in preterm lamb lungs. Am J Physiol 269:L209-L214

15. Zhang S, Garbutt V, McBride JT 1996 Strain-induced growth of the immature lung. J Appl Physiol 81:1471-1476

16. Nobuhara KK, Fauza DO, DiFiore JW, Hines MH, Fackler JC, Slavin R, Hirschl R, Wilson JM 1998 Continuous intrapulmonary distension with perfluorocarbon accelerates neonatal (but not adult) lung growth. J Pediatr Surg 33:292-298

17. Rannels DE, Rannels SR 1988 Compensatory growth of the lung following partial pneumonectomy. Exp Lung Res 14:157-182

18. Davey MG, Johns DP, Harding R 1998 Postnatal development of respiratory function in lambs studied serially between birth and 8 weeks. Respir Physiol 113:83-93

19. Roy CH, Barnes RJ, Heath MF, Sensky PL 1992 A modified helium dilution technique for measuring small lung gas volumes. J Dev Physiol 17:87-92

20. Jakubowski AE, Billings K, Johns DP, Hooper SB, Harding R 1993 Respiratory function in lambs following prolonged oligohydramnios during late gestation. Pediatr Res 34:611-617

21. Chirgwin JM, Przybyla AE, MacDonald RJ, Rutter WJ 1979 Isolation of biologically active ribonucleic acid from sources enriched with ribonuclease. Biochemistry 18:5294-5299

22. Hooper SB, Han VKM, Harding R 1993 Changes in lung expansion alter pulmonary DNA synthesis and IGF-II gene expression in fetal sheep. Am J Physiol 265:L403L409

23. Minoo P, Segura L, Coalson JJ, King RJ, De'emos RA 1991 Alterations in surfactant protein gene expression associated with premature birth and exposure to hyperoxia. Am J Physiol 161:L386-L392

24. Ikegami M, Wada K, Emerson GA, Rebello CM, Hernandez RE, Jobe AH 1998 Effects of ventilation style on surfactant metabolism and treatment response in preterm lambs. Am J Respir Crit Care Med 157:638-644

25. Tsuno K, Prato P, Kolobow T 1990 Acute lung injury from mechanical ventilation at moderately high airway pressures. J Appl Physiol 69:956-961

26. Pasternack M, Jr., Liu X, Goodman RA, Rannels DE 1997 Regulated stimulation of epithelial cell DNA synthesis by fibroblast- derived mediators. Am J Physiol 272:L619-L630

27. Nakamura T, Liu M, Mourgeon E, Slutsky A, Post M 2000 Mechanical strain and dexamethasone selectively increase surfactant protein $\mathrm{C}$ and tropoelastin gene expression. Am J Physiol 278:L974-L980

28. Alcorn DG, Adamson TM, Maloney JE, Robinson PM 1981 A morphologic and morphometric analysis of fetal lung development in the sheep. Anat Rec 201:655667

29. Shannon JM, Jennings SD, Nielsen LD 1992 Modulation of alveolar type II cell differentiated function in vitro. Am J Physiol 262:L427-L436

30. Kasper M, Haroske G 1996 Alterations in the alveolar epithelium after injury leading to pulmonary fibrosis. Histol Histopathol 11:463-483

31. Nobuhara KK, Ferretti ML, Siddiqui AM, Kim SS, Treves ST, Wilson JM 1998 Long-term effect of perfluorocarbon distension on the lung. J Pediatr Surg 33:10241028

32. Bassett JM, Thorburn GD, Wallace AL 1970 The plasma growth hormone concentration of the foetal lamb. J Endocrinol 48:251-263

33. Nardo L, Young IR, Hooper SB 2000 Influence of growth hormone on the lung growth response to tracheal obstruction in fetal sheep. Am J Physiol Lung Cell Mol Physiol 278:L453-L459 